\title{
Chemodiversity of a Scots pine stand and implications for terpene air concentrations
}

\author{
J. Bäck ${ }^{1,2}$, J. Aalto ${ }^{2,3}$, M. Henriksson ${ }^{4}$, H. Hakola ${ }^{4}$, Q. He ${ }^{1}$, and M. Boy ${ }^{1}$ \\ ${ }^{1}$ Department of Physics, University of Helsinki, P.O. Box 64, 00014 University of Helsinki, Finland \\ ${ }^{2}$ Department of Forest Sciences, University of Helsinki, P.O. Box 27, 00014 University of Helsinki, Finland \\ ${ }^{3}$ Hyytiälä Forestry Field Station, Hyytiäläntie 124, 35500 Korkeakoski, Finland \\ ${ }^{4}$ Air Quality Research Unit, Finnish Meteorological Institute, P.O. Box 503, 00101 Helsinki, Finland
}

Correspondence to: J. Bäck (jaana.back@helsinki.fi)

Received: 1 June 2011 - Published in Biogeosciences Discuss.: 26 October 2011

Revised: 22 January 2012 - Accepted: 23 January 2012 - Published: 6 February 2012

\begin{abstract}
Atmospheric chemistry in background areas is strongly influenced by natural vegetation. Coniferous forests are known to produce large quantities of volatile vapors, especially terpenes. These compounds are reactive in the atmosphere, and contribute to the formation and growth of atmospheric new particles.
\end{abstract}

Our aim was to analyze the variability of mono- and sesquiterpene emissions between Scots pine trees, in order to clarify the potential errors caused by using emission data obtained from only a few trees in atmospheric chemistry models. We also aimed at testing if stand history and seed origin has an influence on the chemotypic diversity. The inherited, chemotypic variability in mono- and sesquiterpene emission was studied in a seemingly homogeneous $48 \mathrm{yr}$-old stand in Southern Finland, where two areas differing in their stand regeneration history could be distinguished. Sampling was conducted in August 2009. Terpene concentrations in the air had been measured at the same site for seven years prior to branch sampling for chemotypes.

Two main compounds, $\alpha$-pinene and $\Delta^{3}$-carene formed together $40-97 \%$ of the monoterpene proportions in both the branch emissions and in the air concentrations. The data showed a bimodal distribution in emission composition, in particular in $\Delta^{3}$-carene emission within the studied population. $10 \%$ of the trees emitted mainly $\alpha$-pinene and no $\Delta^{3}$-carene at all, whereas $20 \%$ of the trees where characterized as high $\Delta^{3}$-carene emitters $\left(\Delta^{3}\right.$-carene forming $>80 \%$ of total emitted monoterpene spectrum). An intermediate group of trees emitted equal amounts of both $\alpha$-pinene and
$\Delta^{3}$-carene. The emission pattern of trees at the area established using seeding as the artificial regeneration method differed from the naturally regenerated or planted trees, being mainly high $\Delta^{3}$-carene emitters. Some differences were also seen in e.g. camphene and limonene emissions between chemotypes, but sesquiterpene emissions did not differ significantly between trees. The atmospheric concentrations at the site were found to reflect the species and/or chemodiversity rather than the emissions measured from any single tree, and were strongly dominated by $\alpha$-pinene. We also tested the effect of chemodiversity on modeled monoterpene concentrations at the site and found out that since it significantly influences the distributions and hence the chemical reactions in the atmosphere, it should be taken into account in atmospheric modeling.

\section{Introduction}

Biogenic emissions of volatile organic compounds (BVOC) are significant contributors to air composition in rural areas, and make up roughly $50 \%$ of all atmospheric VOCs (Guenther et al., 1995). BVOCs e.g. influence aerosol growth and formation processes (Claeys et al., 2004; Kulmala et al., 2004; Tunved et al., 2006), and contribute to production and destruction of tropospheric ozone (Atkinson and Arey, 2003), and are thus important factors in atmospheric reactivity. Isoprenoids, such as mono- and sesquiterpenes and isoprene, form a significant proportion of all atmospheric 
reactive BVOCs, and therefore numerous field studies have been conducted to determine their emission rates from vegetation (e.g. Isidorov et al., 1985; Janson, 1992; Tarvainen et al., 2005) and concentrations in the air (e.g. Hakola et al., 2003, 2009).

Monoterpene emission models traditionally use an emission algorithm, where parameters are empirically defined under specific environmental conditions (e.g. Guenther et al., 2006; Sakulyanontvittaya et al., 2008). One of the greatest problems in the empirical approach seems to be in the generalization of emissions into one number, which would describe the variability in emissions over a range of conditions and species. Large seasonal variations exist both in emitted quantities and in the emission composition (e.g. Tarvainen et al., 2005; Holzke et al., 2006), emphasizing the need for a detailed understanding of processes involved, in order to create accurate predictions on emissions and their variations in space and time (Rinne et al., 2009). The empirical algorithms have been recently criticized by Niinemets et al. (2010a, b), based on the missing physico-chemical controls and lack of spatio-temporal resolution in the empirical approach. Monoterpene production is controlled by temperature and light conditions, but also the $\mathrm{CO}_{2}$ concentration and compound volatility influence either the production or diffusion from tissues, thus some process-based models taking into account these dynamic factors have been developed for isoprene and monoterpenes (Niinemets et al., 2002; Bäck et al., 2005; Possell et al., 2005; Arneth et al., 2007; Schurgers et al., 2009).

Boreal coniferous forests are covering vast areas in the northern hemisphere (FAO, 2010), and thus the emissions of BVOCs from these areas play an important role in the atmospheric composition regionally and globally. Among the most important volatile compounds emitted from boreal coniferous forests are monoterpenes and sesquiterpenes, which form a major proportion of the conifer oleoresin (Fäldt et al., 2001) and contribute to the constitutive emissions from trunks, needles and roots. The oleoresin is formed in e.g. in epithelial cells of resin ducts of needles (Fig. 1), and liberated from there in the occasion of a mechanical damage. However, monoterpenes and isoprene are also synthesized in mesophyll cells of conifer needles, and most probably the emissions from mesophyll through stomata form a significant part of the constitutive emissions from needles (Ghirardo et al., 2010). The intra-specific variation of monoterpene blend in e.g. Scots pine oleoresin seems to be quite large (Maciag et al., 2007; Thoss et al., 2007), and distinct chemotypes, i.e. genetically determined monoterpene composition, can be defined from needle essential oils. Already in early 1970's, a clear inherited monoterpene pattern in Scots pine (Pinus sylvestris L.) needle extracts was reported (Hiltunen, 1976). Tarvainen et al. (2005) found that the branch scale emissions of Scots pine individuals were dominated by either $\Delta^{3}$-carene or pinenes (both $\alpha$-pinene and $\beta$-pinene), depending on the location of measurements.

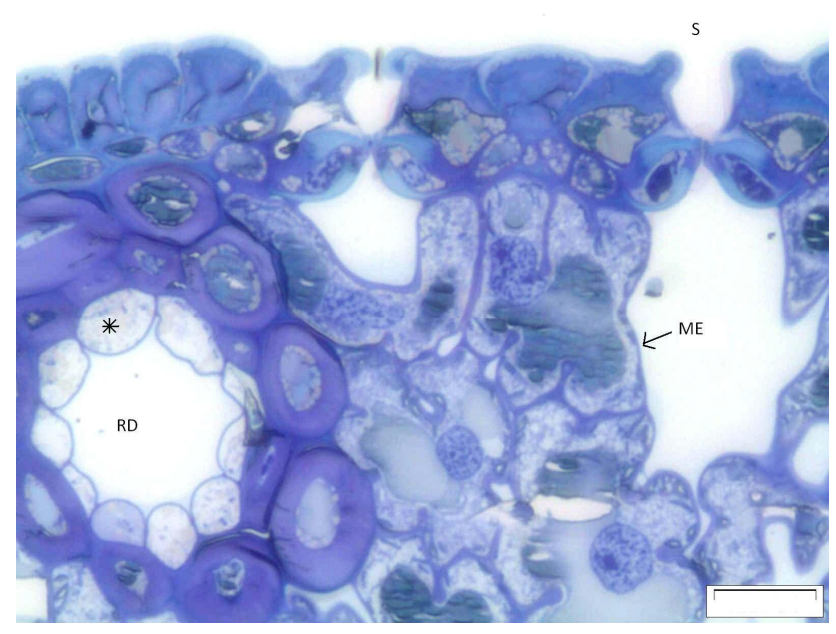

Fig. 1. A light micrograph of a Scots pine needle cross section. The sectioning was done from a resin-embedded needle and the $2 \mu \mathrm{m}$ thick section was stained with Toluidine blue according to Bäck et al. (1994). $\mathrm{RD}=$ resin duct; $\mathrm{ME}=$ mesophyll cell; $\mathrm{S}=$ stoma; $*$ = epithelial cell. $\mathrm{Bar}=50 \mu \mathrm{m}$.

Individual VOCs differ in their atmospheric lifetime and reactivity, and thus it is important to know the composition of the emission blend for modelling the atmospheric chemistry. However, parameterization of atmospheric chemistry models is often done using data from a single tree at a single point of time. Our hypothesis was that this may not be sufficient in describing the impact of the boreal coniferous forest to chemistry above the stand, due to the variation in the inherited emission pattern, chemotype. Therefore we chose to sample branches from trees in a mature Scots pine stand in Southern Finland, where also detailed air chemistry and VOC emission measurements have been conducted over several years. Chemotypic characterization of the stand can reveal the reasons for observed discrepancy between branch scale emissions and above-canopy concentrations and is therefore a key for understanding the implications on air chemistry at the boundary layer.

\section{Methods}

\subsection{Site description and sampling}

The study was carried out at the SMEAR II (Station for Measuring forest Ecosystem - Atmosphere Relations) site in Hyytiälä, Southern Finland ( $61^{\circ} \mathrm{N}, 24^{\circ} \mathrm{E}, 180 \mathrm{~m}$ a.s.1.) in August 2009. The station is situated at a relatively homogenous stand, dominated by 48 yr-old Scots pine with some Norway spruce (Picea abies [L] Karst.) as understorey (Hari and Kulmala, 2005; Ilvesniemi et al., 2009). The proportion of Scots pine is $93 \%$, Norway spruce and deciduous trees (mainly silver and downy birch (Betula pendula [Roth.] and Betula pubescens [Ehrh.]) and European aspen 
(Populus tremula)) are present with proportions of $2 \%$ and $5 \%$, respectively. Within a $200 \mathrm{~m}$ radius from the SMEAR II station, all stands are dominated by Scots pine $(75 \%)$. The Scots pine basal area at the SMEAR II stand is $23 \mathrm{~m}^{2} \mathrm{ha}^{-1}$, and the dominating pines have an average DBH of $19.6 \mathrm{~cm}$. The canopy reaches a height of about $17.5 \mathrm{~m}$. Understorey vegetation is mainly formed from woody shrubs (Vaccinium myrtillus, Vaccinium vitis-idaea and Calluna vulgaris) and mosses (Dicranum polysetum, Pleurozium schreberi). The soil at the stand is mainly podzolic, characterized by thin humus layer and low nitrogen level.

The SMEAR II stand was established mainly by sowing after prescribed burning conducted in 1962. According to old stand management information kept by the Metsähallitus (Administration of states forests) (Hämeenlinnan maakuntaarkisto, 2011), some Scots pine and Norway spruce seedlings have been planted to the SMEAR II stand four years after sowing, in 1966 to fill in gaps. However, sowing was the main regeneration method at the stand. On the contrary, sowing was not used as a regeneration method at all in the adjacent stands, which were regenerated from seeds originating from the close-by mature trees, or by planting with commercially available seedlings. Scots pine is dominating also in most of the surrounding stands, but within the $200 \mathrm{~m}$ radius also some Norway spruce - mixed deciduous stands exist. Within the $200 \mathrm{~m}$ radius the ages of the stands vary from 27 to $85 \mathrm{yr}$ and the proportion of Norway spruce is $15 \%$ and deciduous trees $10 \%$.

We collected branches from 40 pine trees with a systematic sampling scheme (Fig. 2). 25 sample trees were located at the SMEAR II stand and 15 at surrounding pine stands. The middle point of sampling grid was the main mast (length $73 \mathrm{~m}$ ) located in the center of SMEAR II measurement station area. In respect to the main mast the closest sampled trees were at the distance of $5 \mathrm{~m}$ whereas the furthermost ones were $185 \mathrm{~m}$ away. In the selection of sampling plots more emphasis was given to those plots that were located closer to SMEAR II main mast, in order to compare the branch emissions with air concentrations, measured close to the main mast. The probability of the closest plots to be selected was two-fold when compared to the plots that were located farthest off. Between the closest and the farthest plots the probability changed linearly. Branches were collected from upper part of canopy (height 12-14 m), southward facing direction with the help of pole-clippers, and placed immediately in a styrofoam box at $+4^{\circ} \mathrm{C}$. Sampled branches were ca. $20 \mathrm{~cm}$ in length, and included the two most recent age classes of one shoot per tree (about 100-200 needle pairs). The ambient ozone concentrations during sampling ranged from 15 to $35 \mathrm{ppb}$, and those of $\mathrm{NO}_{\mathrm{x}}$ from 0.1 to $1.5 \mathrm{ppb}$.

\subsection{Emission analysis}

The collected branches were stored in cold $\left(<+4^{\circ} \mathrm{C}\right)$ in plastic bags before sampling VOC emissions onto Tenax TA-
Carbopack-B adsorbent in standard laboratory conditions. Emissions were measured immediately after they were transported to the laboratory, not more than 10 days from sampling. By the time of measurement, the cutting-induced resin leakage had ceased and a dry resin plug was formed in the end of the twig. The branches were taken into room temperature 15-40 min before sampling and enclosed in a Teflon bag. We were interested in monoterpene ratios in the emissions of different trees, and thus the analysis was qualitative.

The adsorbent tubes were analysed using a thermodesorption instrument (Perkin-Elmer TurboMatrix 650 ATD) connected to a gas chromatograph-mass spectrometer (PerkinElmer Clarus 600) with HP-1 column $(60 \mathrm{~m}$, i.d. $0.25 \mathrm{~mm})$. The detection limits were $10-200 \mathrm{ng} \mathrm{m}^{-3}$ for most of the compounds. The measured compounds were identified using authentic standards and NIST library.

For analyzing the seasonal variability in monoterpene proportions in Scots pine emission, we also used an old dataset (monthly average emission values from year 2003), reported earlier in Tarvainen et al. (2005).

\subsection{Monoterpene concentrations in the air at the SMEAR II stand}

Air samples were collected between years 2001-2007 for ambient air concentration measurements. The air sampling was done initially above the canopy on the upper level of a scaffolding tower, $10 \mathrm{~m}$ from the main mast. During the measurement period the average Scots pine canopy height in the footprint area increased with $2.1 \mathrm{~m}$, from $15.1 \mathrm{~m}$ to $17.2 \mathrm{~m}$, due to the average annual height growth of $0.3 \mathrm{~m}$ (Ilvesniemi et al., 2009).

The full set of data is reported in Hakola et al. (2009). Here we use only monoterpene data obtained in July-August each year. Samples were collected for $60 \mathrm{~min}$ about three times a week, two samples at a time, and always around noon. Two $\mathrm{MnO}_{2}$-coated copper nets placed in a Teflon holder were employed in front of the sampling tubes for removing ozone from the ambient air. The nets were found to destroy about $80 \%$ of the ozone but leave $\alpha$-pinene, $\beta$-pinene, limonene and $\Delta^{3}$-carene unaffected.

\subsection{Modelling}

The one-dimensional chemistry-transport model SOSA (Model to Simulate the concentrations of Organic vapors and Sulphuric Acid, Boy et al., 2011) was used to investigate the atmospheric relevance of monoterpene chemodiversity for the SMEAR II station in Hyytiälä, Finland.

The meteorology of SOSA is described by a onedimensional version of the SCADIS model (Sogachev et al., 2002; Sogachev and Panferov, 2006). Based on the Reynolds averaged Navier-Stokes (RANS) equations, SCADIS employs a turbulent kinetic energy - specific dissipation closure scheme. The model includes prognostic equations for 

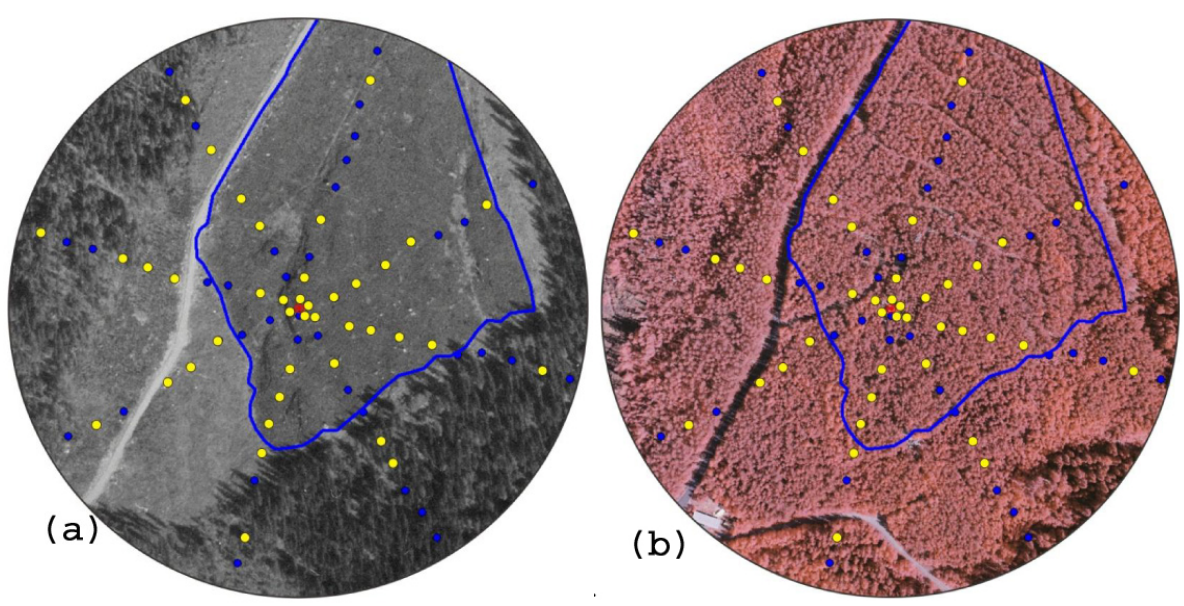

Fig. 2. Aerial photographs of the sample area. Sampling grid is marked with blue (no sample) and yellow (sampled) circles. (a) SMEAR II stand (marked with blue line) and neighbouring stands in 1962; (b) Same stands in 1997. Red dot = mast; diameter of circle $400 \mathrm{~m}$.

these variables and for wind, heat and moisture. Involving a number of parameterizations the model is capable of describing in a realistic manner the physical processes forming the meteorological regime within and above the forest canopy under different environmental conditions (Boy et al., 2011). Measured data from year 2007 at the SMEAR II were used as input and meteorological data (temperature, humidity and wind speed, at 4, 8, 16, 33, 50 and $67 \mathrm{~m}$ heights) were applied for nudging the model variables towards the observations.

The chemistry was calculated using the Kinetic PreProcessor (KPP) (Damian et al., 2002). Most chemical reaction equations were selected from the Master Chemical Mechanism (http://mcm.leeds.ac.uk/MCM/). The photochemistry calculates the photo dissociation constants using data from Atkinson et al. (1992) and spectral irradiance measurements from the SMEAR II station (Boy et al., 2002).

The emissions of organic vapors from the canopy were calculated with a modification of the model MEGAN (Model of Emissions of Gases and Aerosols from Nature), version 2.04 (Guenther et al., 2006). This model, which has been implemented in SOSA, estimates landscape average emission factors for a specific location by combining estimates of plant species composition and representative species-specific emission factors. For each time step, emissions driven by changes in calculated leaf temperature and incident solar radiation on sun and shade leaves at different canopy levels are calculated. We have assumed the landscape to be composed of Scots pine and use standard emission potentials by Hakola et al. (2006). This is a good first order approximation even though it neglects the influence of other plant species in the concentration footprint (e.g. Haapanala et al., 2007). Also 16 different canopy characteristics, such as leaf data together with scattering and reflection coefficients were used to describe the needle forest.

\subsection{Statistics}

The data was tested for chemotypic differences in monoterpene and sesquiterpene emission patterns using nonparametric tests and $k$-means clustering. The tests were conducted for qualitative emission blend data, which was the emission of the emitted compound divided with the sum of emissions of all measured compounds.

$K$-means clustering was conducted using 3 and 4 clusters as input. Two datasets were used for clustering: (1) proportions of the major compounds $\Delta^{3}$-carene and total pinenes $(\alpha$-pinene $+\beta$-pinene) and (2) proportions of all measured compounds. When results of SMEAR II stand and surrounding stands were compared, the number of samples was 25 and 15, respectively. The non-parametric Kruskal-Wallistest was used for testing distributions between groups that were formed using clustering. Correlations between emitted compounds were tested using Pearson correlation coefficient. The non-parametric Mann-Whitney U-test was conducted separately for proportions of $\Delta^{3}$-carene, $\alpha$-pinene and $\beta$-pinene between samples from SMEAR II stand and surrounding stands.

\section{Results}

\subsection{Proportions of mono- and sesquiterpenes in individual Scots pine trees}

The average relative emission content of sampled branches included $\Delta^{3}$-carene and $\alpha$-pinene in almost equal proportions, about $40 \%$ both. The proportion of $\beta$-pinene was little less than $10 \%$. The rest, less than $10 \%$, included all other compounds (in decreasing order): limonene, camphene, isoprene, terpinolene, toluene, benzene, p-cymene, 1,8-cineol, $\beta$-caryophyllene, methylbutenol, alloaromaden- 
Table 1. Averages and standard deviations (sd) for proportions of monoterpenes and sesquiterpenes in total terpenoid emission, differentiated into chemotype groups, and averaged over the whole dataset.

\begin{tabular}{|c|c|c|c|c|c|c|c|c|}
\hline & \multicolumn{2}{|c|}{$\begin{array}{l}\text { Pinene trees } \\
\quad(n=15)\end{array}$} & \multicolumn{2}{|c|}{$\begin{array}{l}\text { Intermediate trees } \\
\quad(n=17)\end{array}$} & \multicolumn{2}{|c|}{$\begin{array}{l}\text { Carene trees } \\
\quad(n=8)\end{array}$} & \multicolumn{2}{|c|}{$\begin{array}{c}\text { Average of all trees } \\
\quad(n=40)\end{array}$} \\
\hline & mean & $\mathrm{sd}$ & mean & sd & mean & sd & mean & sd \\
\hline \multicolumn{9}{|l|}{ MONOTERPENES } \\
\hline$\alpha$-pinene & 0.601 & 0.165 & 0.420 & 0.061 & 0.169 & 0.052 & 0.437 & 0.193 \\
\hline$\Delta^{3}$-carene & 0.144 & 0.104 & 0.445 & 0.080 & 0.764 & 0.062 & 0.396 & 0.246 \\
\hline$\beta$-pinene & 0.171 & 0.173 & 0.053 & 0.043 & 0.018 & 0.013 & 0.090 & 0.125 \\
\hline limonene & 0.037 & 0.066 & 0.019 & 0.021 & 0.003 & 0.001 & 0.023 & 0.043 \\
\hline camphene & 0.018 & 0.009 & 0.022 & 0.015 & 0.008 & 0.005 & 0.018 & 0.013 \\
\hline terpinolene & 0.003 & 0.003 & 0.008 & 0.006 & 0.020 & 0.010 & 0.009 & 0.009 \\
\hline p-cymene & 0.001 & $<0.0005$ & 0.001 & $<0.0005$ & 0.001 & $<0.0005$ & 0.001 & $<0.0005$ \\
\hline 1,8-cineol & $<0.0005$ & $<0.0005$ & 0.001 & 0.001 & 0.001 & 0.001 & 0.001 & 0.001 \\
\hline \multicolumn{9}{|l|}{ SESQUITERPENES $\left(\times 10^{-3}\right)$} \\
\hline$\beta$-caryophyllene & 0.39 & 0.46 & 1.14 & 2.60 & 0.50 & 0.49 & 0.73 & $1 . .74$ \\
\hline alloaromadendr./farnesene & 0.18 & 0.47 & 0.84 & 2.73 & 0.16 & 0.41 & 0.45 & 1.81 \\
\hline$\alpha$-humulene & 0.17 & 0.43 & 0.75 & 2.55 & 0.19 & 0.50 & 0.42 & 1.69 \\
\hline aromadendrene & 0.15 & 0.46 & 0.76 & 2.75 & 0.13 & 0.38 & 0.41 & 1.81 \\
\hline iso-longifolene & 0.13 & 0.36 & 0.62 & 2.14 & 0.16 & 0.43 & 0.35 & 1.42 \\
\hline longicyclene & 0.11 & 0.31 & 0.54 & 1.86 & 0.12 & 0.34 & 0.30 & 1.23 \\
\hline
\end{tabular}

drene/farnesene, bornylacetate, $\alpha$-humulene, aromadendrene, iso-longifolene, longicyclene and nopinone (Table 1). Large differences in relative emission contents between the studied Scots pines were found (Table 1). $\alpha$-pinene and $\Delta^{3}$ carene formed together 40-97\% of the branch monoterpene proportions. Only in one tree the $\beta$-pinene proportion overruled these two major components. Variation was also observed in sesquiterpene composition (Table 1).

The data was analyzed with cluster analysis to reveal potential groupings based on emitted compound spectrum. Three separate clusterings were conducted: (I) three clusters, only proportions of major compounds $\left(\Delta^{3}\right.$-carene and total pinenes $(\alpha$-pinene $+\beta$-pinene) $)$, (II) three clusters, proportions of all measured compounds, (III) four clusters, proportions of all measured compounds. Figure 3 illustrates the average proportions of compounds in 3 clusters based only on the main emitted compounds (type I clustering). This clustering (three clusters, only proportions of major compounds) was used as a basis for further analysis because it is based on the compounds characterizing majority of the variation between trees. These clusters were considered as chemotypes. When all measured compounds were used for dividing trees to 3 clusters (II), the number of high pinene emitters was reduced, and the number of intermediate trees was increased (data not shown). The difference was mainly due to the high $\beta$-pinene emitters shifting from the pinene cluster to the intermediate cluster.

A significant proportion $(20 \%)$ of the pine population could be characterized as high $\Delta^{3}$-carene emitters. The $\Delta^{3}$ - carene emissions of this group were on average $76 \%$ of the total emitted monoterpenes. In minimum their pinene emissions were only one tenth of the $\Delta^{3}$-carene emissions, and the emissions of other monoterpenes were also rather small (on average $<2 \%$ ). Fifteen trees $(37.5 \%)$ emitted mostly $\alpha$-pinene and $\beta$-pinene. From this group, five trees emitted only remnants of $\Delta^{3}$-carene (less than $10 \%$ of total measured emissions), and their pinene emissions were over $90 \%$ of total emission content. In the pinene trees also significant emissions of limonene (ca. $4 \%$ ) and $\beta$-pinene (ca. $17 \%$ ) were measured. However, about half of the trees showed an intermediate emission pattern, with $\Delta^{3}$-carene and $\alpha$-pinene being emitted in almost equal proportions.

$0.01-6.9 \%$ of the total BVOC blend was sesquiterpenes (Table 1). The most abundant sesquiterpene was $\beta$-caryophyllene, which formed over $80 \%$ of the total sesquiterpene emissions in more than half of the trees. The proportion of sesquiterpene emission from trees showing intermediate emission composition was on average threefold when compared to trees showing high proportions of $\Delta^{3}$ carene or pinenes. This difference was caused by a couple of high sesquiterpene emitters among intermediate trees.

The proportion of terpinolene was positively correlated with proportions of $\Delta^{3}$-carene $(r=0.68)$ and $\alpha$-pinene $(r=$ $0.65)$. All sesquiterpenes were strongly intercorrelated $(r>$ $0.9, p<0.01$, Pearson correlation) but this phenomenon was caused by a couple of high sesquiterpene emitters. Correlations between monoterpenes and sesquiterpenes were very weak $(0.39<r>-0.14)$. 


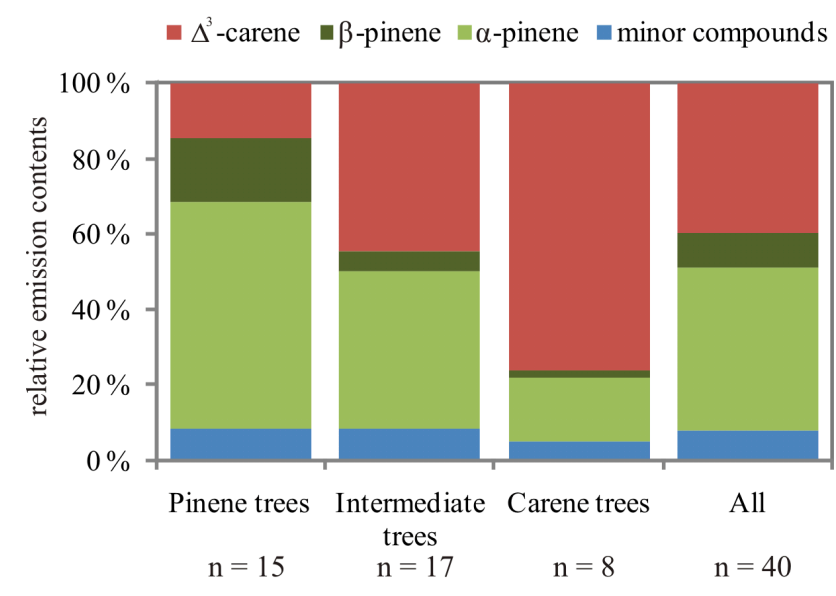

Fig. 3. Average relative emission contents of three clusters. Clustering conducted with the major emitted compounds.

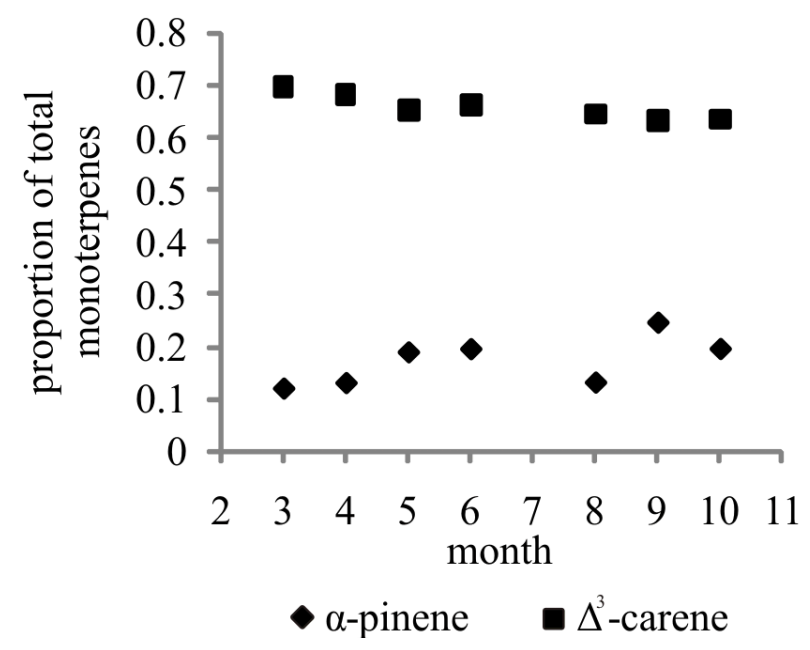

Fig. 4. Variation in proportions (from total monoterpenes) of a-pinene and $\Delta^{3}$-carene in emissions of one tree $\left(\Delta^{3}\right.$-carene chemotype) over one year (2003). Monthly average values $(n=1$ to 10), data from Tarvainen et al. (2005).

We also re-analyzed the emission rates obtained earlier from one " $\Delta^{3}$-carene" chemotype tree (Tarvainen et al., 2005), in order to see if the seasonal emission pattern influences the chemotype (Fig. 4). The results clearly show that even though some changes in relative emission spectrum over the season do occur, the chemotype of an individual tree is not converted from $\Delta^{3}$-carene to pinene-type.

Large variation in relative emission patterns within clusters is evident from Fig. 5. It is clear that especially the group of pinene trees included both trees that emit no $\Delta^{3}$ carene at all and trees that emit some $\Delta^{3}$-carene, whereas all trees, even the highest $\Delta^{3}$-carene emitters, emit some pinenes. Thus it seems that $\alpha$-pinene and $\beta$-pinene always form a part of emissions in Scots pine needles, but that $\Delta^{3}$ carene is a compound that makes the differences between in- dividual trees. When the dataset was divided into four clusters, also the $\beta$-pinene trees were separated from the other clusters (Fig. 6).

Differences in monoterpene distributions between chemotype groups were tested with Kruskal-Wallis test (Table 2). Statistically significant differences in the proportions of $\Delta^{3}$ carene, $\alpha$-pinene and $\beta$-pinene were found, and most of the other monoterpenes also differed between clusters. Only the proportions of 1,8-cineol and sesquiterpenes were not statistically different.

\subsection{Stand-level differences in emissions}

The branch samples were taken from two stands differing in their stand history, namely the SMEAR II and the surrounding stands (see Fig. 2). The average relative monoterpene emissions of trees from the SMEAR II stand and surrounding stands are shown in Fig. 7. Clear differences in proportions of the major compounds $\left(\Delta^{3}\right.$-carene, pinenes) from the SMEAR II and the surrounding stands could be seen. The samples from the SMEAR II stand contained more $\Delta^{3}$-carene and less $\alpha$-pinene than those from the surrounding trees. Differences in the proportions of minor compounds and $\beta$-pinene between the SMEAR II stand and surrounding stands were small (Table 3 ).

The average emission blend in SMEAR II was quite similar to the average emission blend of the trees classified earlier as intermediate, whereas in the surrounding stands the pinene-chemotype seemed to dominate. When distributions of emitted compounds between stands were tested with Mann-Whitney U-test, significant differences in the distributions of $\alpha$-pinene, $\Delta^{3}$-carene, $\beta$-pinene, limonene and $\mathrm{p}$ cymene were found (Table 3 ). Among sample trees from surrounding stands there was only one $\Delta^{3}$-carene tree, whereas SMEAR II stand sample trees included same number of $\Delta^{3}$ carene and pinene trees (Table 3).

\subsection{Air concentrations}

The atmospheric concentrations of monoterpenes at the SMEAR II site were largely dominated by $\alpha$-pinene (Fig. 8) (see also Hakola et al., 2009). The relative proportions of apinene and $\Delta^{3}$-carene remained rather stable over the whole measured period, 2001-2007. Only in 2002 the air concentrations of $\alpha$-pinene and $\Delta^{3}$-carene were close to each other. This is the year when the stand was thinned (see Vesala et al., 2005).

\subsection{Impacts of chemodiversity on atmospheric chemistry modelling}

The emission scheme used in SOSA has been verified recently in two publications by comparing measured and modeled gas phase VOC concentrations (Boy et al., 2011; Mogensen et al., 2011). The results showed good agreement between the model and the measurements, and in this study 


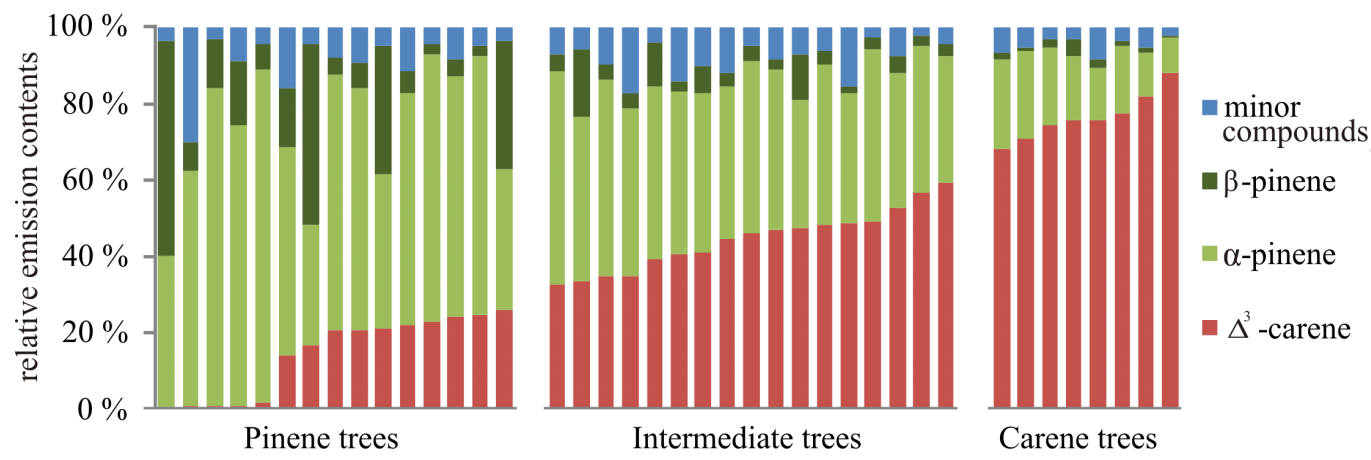

Fig. 5. Relative emission contents of individual trees, clustered as Pinene $(n=15)$, Intermediate $(n=17)$ and Carene trees $(n=8)$. Clustering conducted with the major emitted compounds (type I clustering).

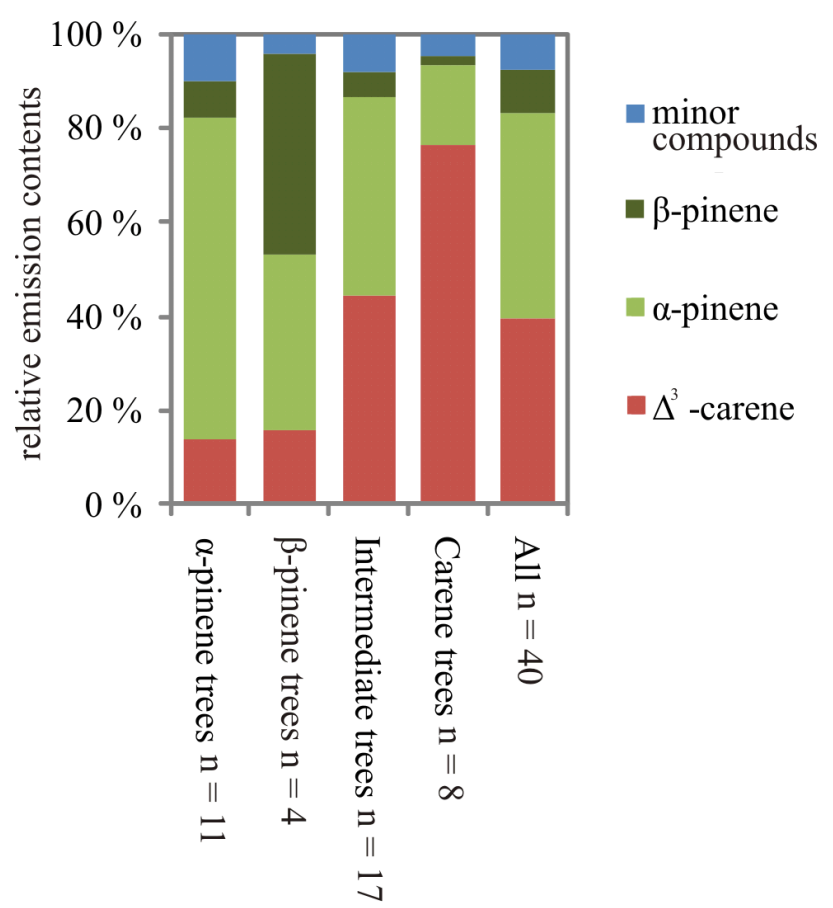

Fig. 6. Average relative emission contents of four clusters (type III clustering). Clusters are named as $\alpha$-pinene trees, $\beta$-pinene trees, intermediate trees and Carene trees.

we will apply SOSA with the same settings and only vary the chemotype-distribution regarding to Table 1. Figure 9 gives the monthly mean concentrations for the sum of monoterpenes at $12 \mathrm{~m}$ height for the year 2007, differentiated between the three chemotypic groups, and also averaged over the whole population. Clear differences, between $30-50 \%$ depending on the month, in the total monoterpene concentrations for the model using $\alpha$-pinene and $\Delta^{3}$-carene chemotypes are visible. The intermediate chemotype is located between the two other groups and the calculated monoterpene concentrations in the intermediate chemotype are very similar to the average for all tree individuals in the population (Fig. 9).

\section{Discussion}

\subsection{Chemodiversity and terpenoid emissions}

In many plants the volatile organic compounds consist of a mixture, where each compound has specific chemical and physical properties and this gives the emissions a complex character. Intraspecies diversity has earlier been characterized from essential oils in plant tissues and cortical oleoresin, where it may be related to resistance towards herbivory, pathogens or some other stresses (e.g. Sjödin et al., 2000; Maciag et al., 2007). We show here that a similar diversity can also be seen in terpene emissions from trees, and that $\Delta^{3}$-carene is clearly the compound that makes the difference between emission blends of individual Scots pine trees. This is in accordance with previous studies on oleoresin composition by e.g. Hiltunen $(1975,1976)$, Yadzani et al. (1985) and Orav et al. (1996). In our study material $\alpha$-pinene and $\beta$ pinene were present in each individual tree, although in some cases in relatively low proportions. However, there were several trees that were emitting practically no $\Delta^{3}$-carene at all. The clear bimodality and grouping of trees into high and low $\Delta^{3}$-carene chemotypes suggests a strong monogenic control for the production of $\Delta^{3}$-carene in pine needles, as was already inferred by Hiltunen et al. (1975). Also in Slash pine (Pinus elliottii Engelm.) the myrcene and $\beta$-pinene composition in the oleoresin of cortical tissues was shown to be bimodal and thus involving only a few genes (Squillace, 1971; Gansel and Squillace, 1976). In our data, the emission blend in pinene chemotype trees contained also other terpene compounds (camphene, limonene) in higher proportions than that of the $\Delta^{3}$-carene -chemotype. Further, the sesquiterpene emission varied also somewhat with chemotype, their proportion of the total emission being highest in the intermediate chemotype.

Previous studies clearly show that the monoterpene composition is influencing the herbivore resistance of plants, and is thus a product of evolutionary development with herbivore pressure. Terpene chemotypes have also been used for species identification in genetic research (e.g. Hiltunen, 
Table 2. Results of the Kruskal-Wallis -test for the proportions of emitted compounds. Statistically significant differences ( $p<0.05)$ between the clusters are marked with ${ }^{* *}$.

\begin{tabular}{lrrrr}
\hline & $\begin{array}{r}\text { Mean rank Pinene trees/ } \\
\text { Intermediate trees/ } \\
\text { Carene trees }\end{array}$ & Test statistic & $p$ & \\
& & & & \\
\hline MONOTERPENES & & & & \\
$\alpha-$ pinene & $29.40 / 20.18 / 4.50$ & 23.692 & $<0.0005$ & $* *$ \\
$\Delta^{3}$-carene & $8.00 / 24.00 / 36.50$ & 33.659 & $<0.0005$ & $* *$ \\
$\beta$-pinene & $28.87 / 19.41 / 7.12$ & 18.302 & $<0.0005$ & $* *$ \\
limonene & $25.93 / 21.35 / 8.50$ & 11.760 & 0.003 & $* *$ \\
camphene & $22.40 / 23.76 / 10.00$ & 8.176 & 0.017 & $* *$ \\
terpinolene & $10.93 / 22.18 / 34.88$ & 22.491 & $<0.0005$ & $* *$ \\
p-cymene & $11.53 / 28.18 / 21.00$ & 16.169 & $<0.0005$ & $* *$ \\
1,8 -cineol & $17.20 / 25.53 / 16.00$ & 5.527 & 0.063 & \\
\hline SESQUITERPENES & & & & \\
$\beta$-caryophyllene & $18.97 / 20.97 / 22.38$ & 0.491 & 0.782 & \\
alloaromadendr./farnesene & $19.73 / 23.47 / 15.62$ & 2.645 & 0.267 & \\
$\alpha$-humulene & $19.33 / 21.85 / 19.81$ & 0.405 & 0.817 & \\
aromadendrene & $22.80 / 19.15 / 19.06$ & 1.904 & 0.386 & \\
iso-longifolene & $20.60 / 21.21 / 18.81$ & 0.230 & 0.891 & \\
longicyclene & $22.00 / 20.74 / 17.19$ & 0.971 & 0.615 & \\
\hline
\end{tabular}

Table 3. Means and standard deviations of proportions of all measured monoterpenes and sesquiterpenes from trees at the SMEAR II stand and at surrounding stands. Results of the Mann-Whitney U-tests for the proportions of different compounds. Statistically significant differences $(p<0.05)$ between the SMEAR II stand and surrounding stands are marked with **. Number of trees in each cluster at SMEAR II stand and surrounding stands.

\begin{tabular}{|c|c|c|c|c|c|c|c|c|}
\hline & \multicolumn{2}{|c|}{$\begin{array}{l}\text { SMEAR II stand } \\
\quad(n=25)\end{array}$} & \multicolumn{2}{|c|}{$\begin{array}{l}\text { Surrounding stands } \\
\quad(n=15)\end{array}$} & \multirow[t]{2}{*}{$\begin{array}{l}\text { Mean rank SMEAR II/ } \\
\text { Surrounding stands }\end{array}$} & \multirow[t]{2}{*}{$\mathrm{U}$} & \multirow[t]{2}{*}{$p$} & \\
\hline & mean & sd & mean & $\mathrm{sd}$ & & & & \\
\hline \multicolumn{9}{|l|}{ MONOTERPENES } \\
\hline$\alpha$-pinene & 0.39 & 0.19 & 0.51 & 0.17 & $17.68 / 25.20$ & 258 & 0.049 & $* *$ \\
\hline$\Delta^{3}$-carene & 0.47 & 0.24 & 0.28 & 0.20 & $24.08 / 14.53$ & 98 & 0.012 & $* *$ \\
\hline$\beta$-pinene & 0.07 & 0.12 & 0.12 & 0.13 & $17.68 / 25.20$ & 258 & 0.049 & ** \\
\hline limonene & 0.012 & 0.016 & 0.041 & 0.065 & $17.16 / 26.07$ & 271 & 0.020 & $* *$ \\
\hline camphene & 0.016 & 0.013 & 0.021 & 0.012 & $18.60 / 23.67$ & 235 & 0.185 & \\
\hline terpinolene & 0.011 & 0.010 & 0.005 & 0.003 & $23.24 / 15.93$ & 119 & 0.056 & \\
\hline p-cymene & 0.001 & $<0.001$ & 0.001 & $<0.001$ & $23.56 / 15.40$ & 111 & 0.033 & $* *$ \\
\hline 1,8 -cineol & 0.001 & 0.001 & $<0.001$ & $<0.001$ & $22.76 / 16.73$ & 131 & 0.114 & \\
\hline \multicolumn{9}{|l|}{ SESQUITERPENES $\left(\times 10^{-3}\right.$} \\
\hline$\beta$-caryophyllene & 0.85 & 2.14 & 0.53 & 0.71 & $20.36 / 20.73$ & 191 & 0.922 & \\
\hline aromadendrene & 0.57 & 2.27 & 0.13 & 0.41 & $20.52 / 20.47$ & 187 & 0.984 & \\
\hline$\alpha$-humulene & 0.57 & 2.12 & 0.16 & 0.43 & $20.32 / 20.80$ & 192 & 0.900 & \\
\hline alloaromadendr./farnesene & 0.61 & $2-27$ & 0.20 & 0.43 & $19.12 / 22.80$ & 222 & 0.327 & \\
\hline iso-longifolene & 0.47 & 1.77 & 0.13 & 0.39 & $20.58 / 20.37$ & 185 & 0.955 & \\
\hline longicyclene & 0.40 & 1.54 & 0.12 & 0.35 & $20.32 / 20.80$ & 192 & 0.896 & \\
\hline Number of Carene trees & \multicolumn{2}{|r|}{7} & \multicolumn{2}{|c|}{1} & & & & \\
\hline Number of Intermediate trees & \multicolumn{2}{|c|}{11} & \multirow{2}{*}{\multicolumn{2}{|c|}{6}} & & & & \\
\hline Number of Pinene trees & \multicolumn{2}{|r|}{7} & 8 & & & & & \\
\hline
\end{tabular}




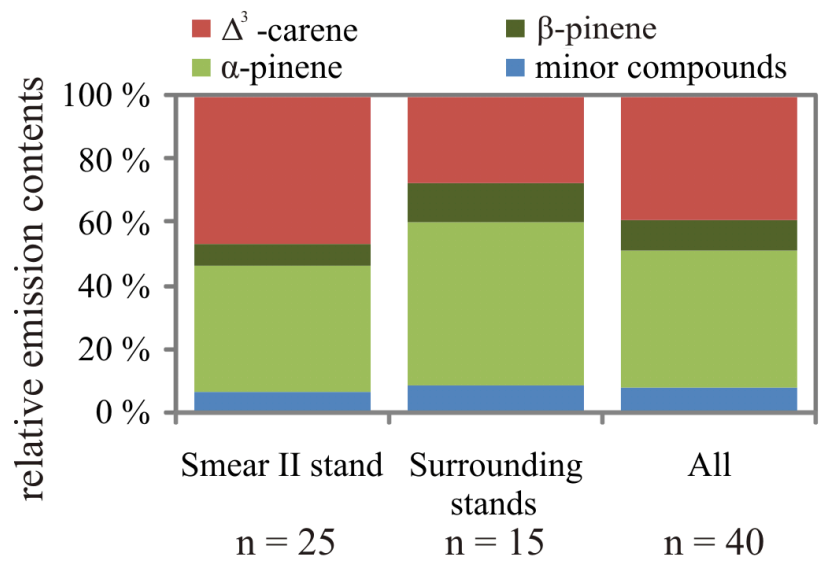

Fig. 7. Average relative emission contents of SMEAR II stand and the surrounding stands, and all 40 sample trees. $n=$ number of trees

1975; Gref and Lindgren, 1984). Chemotypic diversity and bimodal distributions of monoterpenes are seen in oleoresin extracts of many coniferous species, for example Slash pine ( $\beta$-pinene and myrcene, Gansel and Squillace, 1976), Norway spruce $\left(\Delta^{3}\right.$-carene and pinenes, Esteban et al., 1976; Orav et al., 1996), Douglas fir $\left(\Delta^{3}\right.$-carene and pinenes, Latta et al., 2003) and Common juniper (Common juniper $(\alpha-$ pinene and sabinene, Filipowicz et al., 2009).

It has been recognized that the rates of terpenoid emissions from vegetation change significantly with time, and it can be asked if the chemotypic variation also changes with seasons. High quantities of monoterpenes emitted from Scots pine branches have been measured during spring and summer, whereas emissions of sesquiterpenes and some oxygenated compounds are only seen in midsummer period (Tarvainen et al., 2005). The composition of volatiles can also undergo large changes during leaf maturation at least in broad-leaved trees (e.g. Hakola et al., 1998). Our branch material was collected in August, during the maximum emission period, so potential chemotypic variations in the population over time were not studied here. However, based on our earlier results, the chemotype within a branch does not change significantly, although the total emission strength is changing within the season (Fig. 4, see also Tarvainen et al., 2005), and therefore we can conclude that the chemotype is fairly stable over time within a given tree individual. This is consistent with the chemotype being a genetically determined property (e.g. Muona et al., 1986), not influenced by environmental factors.

Emission rates can be influenced by stresses such as mechanical damage (Juuti et al., 1990). In our study, emissions were measured from a cut branch in laboratory, several days after cutting and storage in cold. Our earlier results from emissions after debudding a shoot (Hakola et al., 2006) indicate that high emissions induced after a mechanical damage are sustained only for a few days, and thereafter the emissions decline to a similar level as measured prior wounding.

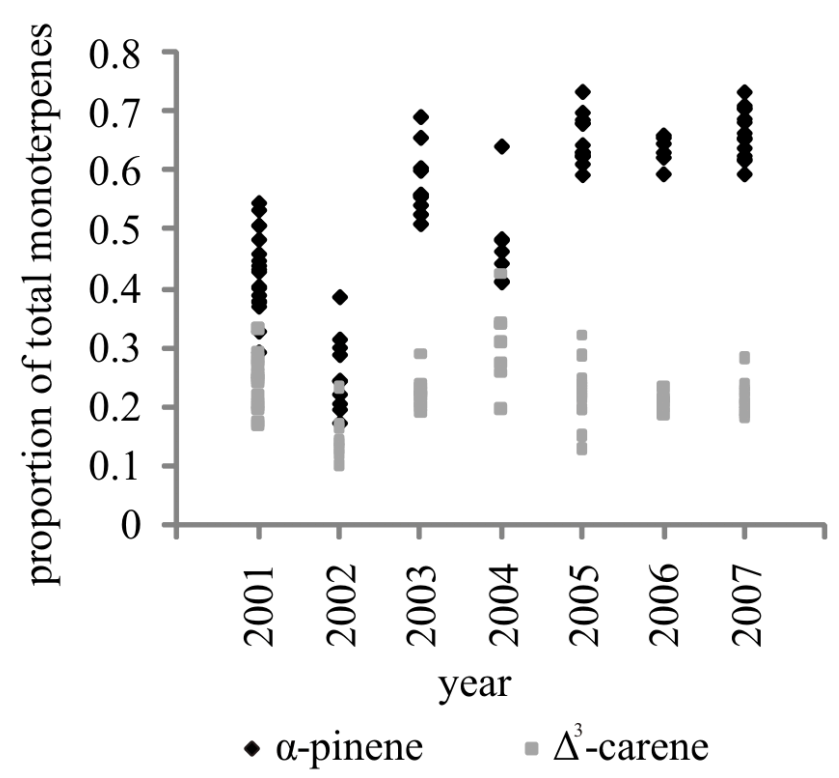

Fig. 8. Summertime (July-August) proportion of $\alpha$-pinene and $\Delta^{3}$ carene from total monoterpenes in the air at SMEAR II between years 2001-2007.

Further, the relative proportions of emitted monoterpenes in the Hakola et al. (2006) study were not influenced by the debudding. Therefore we suggest that the relative monoterpene emissions should not be strongly influenced by the cutting stress in our case, and that these results can therefore be used in estimating the emission variability within a stand.

The emission algorithms used for atmospheric modeling are predicting total emitted quantity rather than the emission quality. However, it is not known, whether the diversity in emission spectrum is also reflected in the total emitted quantities of monoterpenes. According to Latta et al. (2003), the chemodiversity may not influence the total monoterpene quantity in needles, since the regulation of biosynthesis seems to operate at the level of allocation of a limited total pool of monoterpenes among fractions, rather than at the absolute concentrations of individual monoterpenes. In Scots pine the chemodiversity in oleoresin is particularly well documented. A strong heritability in Swedish Scots pines was demonstrated by Baradat et al. (1988) for $\Delta^{3}$-carene, myrcene, limonene and $\beta$-phellandrene, while pinenes and sabinene varied more with environmental factors. The southern pine populations contained more of the high $\Delta^{3}$-carene chemotype trees than northern populations in both Sweden and Finland (Yazdani et al., 1985; Muona et al., 1986; Pohjola, 1993; Manninen et al., 2002), whereas limonene content in pine needles increased towards north (Nerg et al., 1994). This variation was mostly found in natural stands and it was suggested to depend on ecological factors influencing adaptation to differing conditions between south and north (Muona et al., 1986; Pohjola et al., 


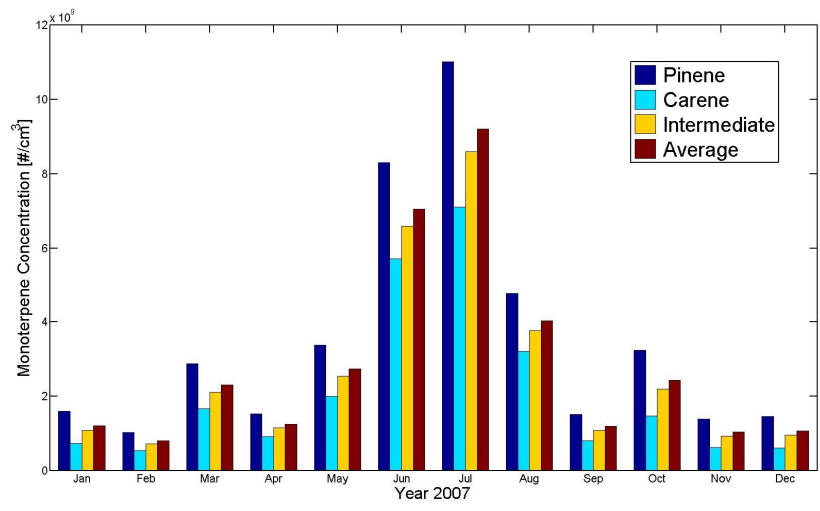

Fig. 9. Modelled monthly mean monoterpene concentrations (molecules $\mathrm{cm}^{-3}$ ) for the year 2007 at SMEAR II using the emissions from Carene, Pinene and Intermediate chemotypes, and the average emission of the population (Table 1).

1993), such as day length and length of growing season. Environmental factors such as light and temperature are accounted for in the present empirical algorithms describing terpene emission rates (e.g. Guenther et al., 2006). Whether this is the case also in Scots pine emissions, remains to be studied in future.

The clustering method was found to be a useful way to divide trees to chemotype groups. It is obvious that the solutions of clustering are highly material dependent: the cutting limits for high and low $\Delta^{3}$-carene emitters can be totally different when clustering is used with some other material. It is worth noticing that both Muona et al. (1986) and Pohjola (1993) used $90 \%$ as a cutting limit for high $\Delta^{3}$ carene emitter, but in our dataset trees with such a high $\Delta^{3}$ carene proportion were not found. However, it seems that $\Delta^{3}$-carene seems to be the compound characterizing the most striking differences between different kinds of emitters, and then the ratio between $\Delta^{3}$-carene and pinenes could be used as an index for a chemotype.

\subsection{Chemodiversity and atmospheric chemistry}

The majority of organic volatiles in background air originate from forest trees (e.g. Guenther et al., 1995; Tarvainen et al., 2007). Scots pine is a predominant conifer in managed and natural forests in large areas of Scandinavia and northern Europe, and thus pine forests have large influence on the chemical composition of background air. Although the chemotypic diversity of Scots pine essential oils has long been known (e.g. Hiltunen et al., 1975), it has largely been ignored in atmospheric studies. This study shows that since the emissions of volatile terpenes from foliage are subject to this wide chemotypic heterogeneity, this diversity has significant impacts on the individual monoterpene concentrations and thus atmospheric chemistry in the boundary layer. Even pure, seemingly homogenous pine stands can exert a variable influence on the chemistry at boundary layer, depending on which chemotypes are present. The different monoterpene concentrations will effect e.g. the radical budget through e.g. higher reaction rates of $\Delta^{3}$-carene compared to $\alpha$-pinene with the hydroxyl (daytime) and the nitrate radical (nighttime). In the case of ozone the ratio of the reaction rates is vice versa, however since the $\mathrm{O}_{3}$ concentrations at SMEAR II are rather low (Boy et al., 2003) the reactions with $\mathrm{O}_{3}$ will produce smaller effects on the monoterpene concentrations than reactions with $\mathrm{OH}$ or nitrate radicals. During more polluted events the reaction with ozone could be more pronounced and merge the total monoterpene concentrations from the pinene and $\Delta^{3}$-carene chemotype groups together.

The implications of chemotypic diversity on modeling the composition of atmosphere are twofold: first, the information currently available on emissions, which is used in air chemistry models seems to be insufficient, when the reactivities of different compounds are taken into account; and second, if also the emission quantity would be affected by emission diversity, then the emission rates based on the screening of only a few trees can be significantly biased. If emission measurements are performed on only one or a few branches/trees, then this may lead into biased conclusions and parameters for such models. The model simulations clearly point out that for understanding the total atmospheric monoterpene concentration, knowledge of the chemotype composition is essential.

Speciated monoterpene emission measurements in field conditions are often conducted using branch enclosures (e.g. Staudt et al., 1997; Tarvainen et al., 2005; Holzke et al., 2006), and emission factors (EFs) are calculated based on these empirical measurements for isoprene and sums of mono- and sesquiterpenes. Due to the laborious sampling and analysis procedure, the number of replicate trees in determining standard emissions at specified conditions is often very limited, and especially the long-term monitoring of compound-speciated branch scale BVOC emissions has been bound to one or a couple of trees. In the current empirical approach, the main external controlling factor for incident monoterpene emissions is temperature (Tingey et al., 1980), although recently also significant light-dependent emissions have been detected from e.g. Scots pine (Shao et al., 2001; Ghirardo et al., 2010). Many caveats have lately been presented towards the original empirical algorithm approach (Niinemets et al., 2010a, b). The compound-specific physico-chemical properties are very variable (Copolovici and Niinemets, 2005) and may influence the EFs (Niinemets et al., 2010a), and since plant emissions are almost always composed of several compounds, the use of a summed emission strength is not sufficient for detailed air chemistry calculations. In longer term, both the quantity and quality of emitted compounds varies diurnally, within the season and along with environmental stressors (e.g. Janson et al., 1999; Tarvainen et al., 2005; Hakola et al., 2006; Holzke et al., 2006), and thus an intrinsic species-specific EF, invariable in time and space is hard to define. 
We propose that chemodiversity is an additional factor, emphasizing the need for deeper understanding of emission dynamics at stand level. The large, chemotypic differences in the composition of emissions in a seemingly homogenous pine stand indicate that branch scale measurements and models based on these may be prone to large experimental biases, and larger scale measurements are necessary for determining the stand emission parameters. Further, not even the current versions of the process-based models can produce compound-specific emission dynamics, and therefore we urgently need a more detailed understanding of the basis of emission variability.

According to our air concentration measurements, abovecanopy concentrations in the site are dominated by $\alpha$-pinene, which on average is three times more abundant than the second most common compound, $\Delta^{3}$-carene (Hakola et al., 2009). The above-canopy concentrations naturally represent very large area, and even with reactive compounds such as monoterpenes, transport distances may be several kilometres (Rinne et al., 2007). Also other tree species than Scots pine inside the footprint area can have an effect on the abovecanopy concentrations. Forests close to the site are dominated by Scots pine, although significant Norway spruce stands are also located in the vicinity. The air concentration measurements were always done on mid day and very close or inside the canopy, which can thus be suggested to represent canopy scale emissions rather well. One important factor is the forestry management, which was potentially seen in the air concentrations during 2002, when thinning of the SMEAR II stand caused a decrease in the proportion of $\alpha$-pinene emission relative to $\Delta^{3}$-carene emission. This suggests that the felled trees were mainly of $\Delta^{3}$-carene chemotype, and a major source for $\Delta^{3}$-carene was the large resin reservoirs which were liberated during felling of the trees.

We also wish to highlight the impact the reaction products of the monoterpenes will have on the formation of secondary organic aerosols. Here we have to consider the still unknown mechanism in the atmospheric nucleation process. Recently Lauros et al. (2010) and Paasonen et al. (2010) claimed that an organic molecule emitted from the biosphere could play a crucial role in the formation of new particles at the SMEAR II site. Until now our understanding is still too limited to make any qualitative statement about this mysterious molecule but in her publication Lauros used the reaction products of all monoterpenes with the hydroxyl radical as a proxy. If only certain monoterpenes are responsible for these reactions, then a chemotype - specific monoterpene distribution can produce significant differences at local or regional scale. The growth of the newly formed particles over the boreal forest is triggered by organic molecules (Tunved et al., 2006) and each monoterpene has a specific aerosol yield leading to different growth rates and cloud condensation nucleus concentrations with important impacts on the radiative aerosol properties. Ebben et al. (2011) show that the organic fraction of submicron aerosol particles collected from
SMEAR II site closely resembles the molecular signature of $\alpha$-pinene, thus confirming the importance of $\alpha$-pinene emissions in the secondary organic aerosol formation processes at this site. A detailed study on the quantitative influence of chemotypic heterogeneity on the $\mathrm{OH}$ - and $\mathrm{NO}_{3}$-radical budget will be presented in further studies.

\subsection{Chemodiversity and stand history}

It was interesting to note that some of the chemotype differences could be attributed to the stand regeneration history even in a rather limited area. The SMEAR II trees showed larger variation in their emission pattern than those in surroundings. There was nearly no high $\Delta^{3}$-carene emitters at the surrounding stands, but at SMEAR II stand there were equal numbers of high and low $\Delta^{3}$-carene emitters. According to the stand history records, the surrounding stands represent mainly local origins, which may be less diverse in their inherited properties than a mixture of trees grown from commercial seeds (such as the SMEAR II stand). The SMEAR II stand is in fact the only stand in the vicinity of SMEAR II measurement station where sowing with commercial seed material has been used as a regeneration method.

During past decades stand regeneration and nursery methods as well as forest tree breeding have been under continuous development in Finland, and as a result of this, for example the sources of seed material have changed. Nowadays majority of seeds used for sowing Scots pine to either nursery or directly to forest after clear cut is collected from specific seed orchards. Those seed orchards have been established in the later part of the 20th century. However, prior to the time when the seed orchards started to produce significant amounts of seed material, seeds for nursery sowings were collected from known high quality trees or stands. At that time, seeds used in nurseries had probably more limited genetic background when compared to seeds used for direct sowing. The main rule in direct sowing was that seeds should not originate too far (either south/north or low/high) from the stand where seeds were sown. Practically no other rules were applied. In a large-scale forestry, large amount of seeds were needed for direct sowing, and they were collected where ever they could be found. This could have lead to large variation in genetic background of seeds.

Muona et al. (1986) reported that in the "plustrees", which are selected particularly for forest tree breeding, there was no geographical pattern related to $\Delta^{3}$-carene emissions. According to both Muona et al. (1986) and Pohjola (1993) north-south variation in the incidence of high $\Delta^{3}$-carene emitters was found in natural stands. Muona et al. (1986) were able to show that favouring other southern features does not explain the lack of geographical variation in the $\Delta^{3}$ carene emissions of plustrees, but this does not preclude a coupling of high $\Delta^{3}$-carene emission and some other feature that is not related to geographical location. Site effects on monoterpene composition of oleoresin with white pine and 
slash pine were very small in several studies (Hanover, 1966; Gansel and Squillace, 1976). Indeed, Gansel and Squillace (1976) concluded that one should avoid characterizing a species by sampling trees in only a few portions of the species range due to the large chemotypic variation.

\section{Conclusions}

The large variation in compound-specific emission patterns influences the stand-level monoterpene concentrations and clear chemotype grouping can be distinguished in Scots pine trees. The chemodiversity implies that at a stand and regional scale, the atmospheric reactivity based on the radical concentrations and the consequent aerosol formation processes evidently also are affected. Since currently the atmospheric chemistry models use parameterizations derived from emission measurements from only one or a few trees, the errors caused by these to the stand-level air chemistry can therefore be high. More comprehensive measurements, process-based modelling involving different chemotypes and populationlevel studies are urgently needed in order to upscale from leaf level to stand or regional level emissions.

A detailed model study on the effects by different chemotypes at the SMEAR II stand for the radicals $\left(\mathrm{OH}\right.$ and $\left.\mathrm{NO}_{3}\right)$ and ozone budget including the consequences for the aerosol formation processes is ongoing and will be published as a follow up manuscript.

Acknowledgements. MSc Janne Levula and the Hämeenlinnan Makunta-arkisto are acknowledged for their help in clarifying the stand history records at the SMEAR II site. The research was supported by the Academy of Finland Center of Excellence program (project number 1118615), the ERC Advanced Grant (project number 227463) and the Graduate school "Atmospheric Composition and Climate Change: From Molecular Processes to Global Observations and Models - Doctoral Programme (ACCC)".

Edited by: H. P. Schmid

\section{References}

Arneth, A., Niinemets, Ü., Pressley, S., Bäck, J., Hari, P., Karl, T., Noe, S., Prentice, I. C., Sera, D., Hickler, T., Wolf, A., and Smith, B.: Process-based estimates of terrestrial ecosystem isoprene emissions: incorporating the effects of a direct $\mathrm{CO}_{2}$-isoprene interaction, Atmos. Chem. Phys., 7, 31-53, doi:10.5194/acp-731-2007, 2007.

Atkinson, R. and Arey, J.: Gas-phase tropospheric chemistry of biogenic volatile organic compounds: a review, Atmos. Environ., 37, 197-219, 2003.

Atkinson, R., Baulch, D. L., Cox, R. A., Hampson Jr., R. F., Kerr, J. A., and Troe, J.: Evaluated kinetic and photochemical data for atmospheric chemistry, Supplement IV, J. Phys. Chem. Ref. Data, 21, 1125-1568, 1992.
Bäck, J., Hari, P., Hakola, H., Juurola, E., and Kulmala, M.: Dynamics of monoterpene emissions in Pinus sylvestris during early spring, Boreal Env. Res. 10, 409-424, 2005.

Baradat, P. and Yadzani, R.: Genetic expression for monoterpenes in clones of Pinus sylvestris grown on different sites, Scand. J. Forest Res., 3, 25-36, 1988.

Boy, M. and Kulmala, M.: The part of the solar spectrum with the highest influence on the formation of SOA in the continental boundary layer, Atmos. Chem. Phys., 2, 375-386, doi:10.5194/acp-2-375-2002, 2002.

Boy, M., Rannik, Ü., Lehtinen, K. E. J., Tarvainen, V., Hakola H., and Kulmala, M.: Nucleation events in the continental PBL long term statistical analysis of aerosol relevant characteristics, J. Geophys. Res., 108, 4667, doi:10.1029/2003JD003838, 2003.

Boy, M., Sogachev, A., Lauros, J., Zhou, L., Guenther, A., and Smolander, S.: SOSA - a new model to simulate the concentrations of organic vapours and sulphuric acid inside the ABL Part 1: Model description and initial evaluation, Atmos. Chem. Phys., 11, 43-51, doi:10.5194/acp-11-43-2011, 2011.

Bäck, J., Neuvonen, S., and Huttunen, S.: Pine needle growth and fine structure after prolonged acid rain treatment in the subarctic, Plant, Cell Environ., 17, 1009-1021, 1994.

Claeys, M., Graham, B., Vas, G., Wang, W., Vermeylen, R., Pashynska, V., Cafmeyer, J., Guyon, P., Andreae, M. O., Artaxo, P., and Maenhaut, W.: Formation of Secondary Organic Aerosols Through Photooxidation of Isoprene, Science, 303, 1173-1176, 2004.

Copolovici, L. and Niinemets, Ü.: Temperature dependencies of Henry's law constants and octanol/water partition coefficients for key plant volatile monoterpenoids, Chemosphere, 61, 13901400, 2005.

Damian, V.: The kinetic pre-processor KPP-a software environment for solving chemical kinetics, Comput. Chem. Eng., 26, 15671579, doi:10.1016/S0098-1354(02)00128-X, 2002.

Ebben, C. J., Martinez, I. S., Shrestha, M., Buchbinder, A. M., Corrigan, A. L., Guenther, A., Karl, T., Petäjä, T., Song, W. W., Zorn, S. R., Artaxo, P., Kulmala, M., Martin, S. T., Russell, L. M., Williams, J., and Geiger, F. M.: Contrasting organic aerosol particles from boreal and tropical forests during HUMPPA-COPEC2010 and AMAZE-08 using coherent vibrational spectroscopy, Atmos. Chem. Phys., 11, 10317-10329, doi:10.5194/acp-1110317-2011, 2011.

Esteban, I., Bergmann, F., Gregorius, H.-R., and Huhtinen, O.: Composition and genetics of monoterpenes from cortical oleoresin of Norway spruce and their significance for clone identifiation, Silvae Genet., 25, 59-66, 1976.

FAO: Global forest resources assessment 2010, FAO Forestry paper 163, FAO, ISBN 978-92-5-106654-6, 2010.

Fäldt, J., Sjödin, K., Persson, M., Valterova, I., and Borg-Karlson, A.-K.: Correlations between selected monoterpene hydrocarbons in the xylem of six Pinus (Pinaceae) species, Chemoecology, 11, 97-106, 2001.

Filipowicz, N., Madanecki, P., Gołebiowski, M., Stepnowski, P., and Ochocka, J. R.: HS-SPME/GC analysis reveals the population variability of terpene contents in Juniperus communis needles, Chem. Biodivers., 6, 2290-2301, 2009.

Gansel, C. R. and Squillace, A. E.: Geographic variation of monoterpene in cortical oleoresin of Slash pine, Silvae Genet., 25, 150-154, 1976. 
Ghirardo, A., Koch, K., Taipale, R., Zimmer, I., Schnitzler, J.-P., and Rinne, J.: Determination of de novo and pool emissions of terpenes from four common boreal/alpine trees by ${ }^{13} \mathrm{CO}_{2}$ labelling and PTR-MS analysis, Plant, Cell Environ., 33, 781-792, doi:10.1111/j.1365-3040.2009.02104.x, 2010.

Gref, R. and Lindgren, D.: The inheritance of pinifolic acid in Scots pine (Pinus sylvestris L.) needles, Silvae Genet., 33, 235-237, 1984.

Guenther, A., Karl, T., Harley, P., Wiedinmyer, C., Palmer, P. I., and Geron, C.: Estimates of global terrestrial isoprene emissions using MEGAN (Model of Emissions of Gases and Aerosols from Nature), Atmos. Chem. Phys., 6, 3181-3210, doi:10.5194/acp-63181-2006, 2006.

Haapanala, S., Rinne, J., Hakola, H., Hellén, H., Laakso, L., Lihavainen, H., Janson, R., O'Dowd, C., and Kulmala, M.: Boundary layer concentrations and landscape scale emissions of volatile organic compounds in early spring, Atmos. Chem. Phys., 7, 1869-1878, doi:10.5194/acp-7-1869-2007, 2007.

Hakola, H., Rinne, J., and Laurila, T.: The hydrocarbon emission rates of tea-leafed willow (Salix phylicifolia), silver birch (Betula pendula) and european aspen (Populus tremula), Atmos. Environ., 32, 1825-1833, 1998.

Hakola, H., Tarvainen, V., Laurila, T., Hiltunen, V., Hellén, H., and Keronen, P.: Seasonal variation of VOC concentrations above a boreal coniferous forest, Atmos. Environ., 37, 1623-1634, 2003.

Hakola, H., Tarvainen, V., Bäck, J., Ranta, H., Bonn, B., Rinne, J., and Kulmala, M.: Seasonal variation of mono- and sesquiterpene emission rates of Scots pine, Biogeosciences, 3, 93-101, doi:10.5194/bg-3-93-2006, 2006.

Hakola, H., Hellén, H., Tarvainen, V., Bäck, J., Patokoski J., and Rinne, J.: Annual variations of atmospheric VOC concentrations in a boreal forest, Boreal Environ. Res., 14, 722-730. 2009.

Hanover, J. W.: Genetics of terpenes. I. Gene control of monoterpene levels in Pinus monticola, Dougl. Heredity, 21, 73-84, doi:10.1038/hdy.1966.5, 1966.

Hari, P. and Kulmala, M.: Station for Measuring EcosystemAtmosphere Relations (SMEAR II), Boreal Environ. Res., 10, 315-322, 2005.

Hiltunen, R.: Variation and inheritance of some monoterpenes in Scots pine (Pinus sylvestris L.), Planta. Med., 28, 315-323, 1975.

Hiltunen, R.: On variation, inheritance and chemical interrelationships of monoterpenes in Scots pine (Pinus sylvestris $\mathrm{L}$.), $\mathrm{PhD}$ thesis, University of Helsinki, Finland. Ann. Acad. Sci. Fenn. Ser. A IV Biol., 208, 1-54, 1976.

Holzke, C., Hoffmann, T., Jaeger, L., Koppmann, R., and Zimmer, W.: Diurnal and seasonal variation of monoterpene and sesquiterpene emissions from Scots pine (Pinus sylvestris L.), Atmos. Environ., 40, 3174-3185, 2006.

Hämeenlinnan maakunta-arkisto, Metsähallituksen Korkeakosken hoitoalueen arkisto: records 33, 34, 35, 38, 39, 51, 54, 55, 58 and 59, 2011.

Ilvesniemi, H., Levula, J., Ojansuu, R., Kolari, P., Kulmala, L., Pumpanen, J., Launiainen, S., Vesala, T., and Nikinmaa, E.: Long-term measurements of the carbon balance of a boreal Scots pine dominated forest ecosystem, Boreal Env. Res. 14, 731-753, 2009.

Isidorov, V. A., Zenkevich, I. G., and Ioffe, B. V.: Volatile organic compounds in the atmosphere of forests, Atmos. Environ., 19, $1-13,1985$.
Janson, R.: Monoterpene concentrations in and above a forest of Scots pine, J. Atmos. Chem., 14, 385-394, 1992.

Janson, R., De Serves, C., and Romero, R.: Emission of isoprene and carbonyl compounds from a boreal forest and wetland in Sweden, Agr. For. Meteorol., 98-99, 671-681, 1999.

Juuti, S., Arey, J., and Atkinson, R.: Monoterpene emission rate measurements from a Monterey pine, J. Geophys. Res., 95, 7515-7519, 1990.

Kulmala, M., Suni, T., Lehtinen, K. E. J., Dal Maso, M., Boy, M., Reissell, A., Rannik, Ü., Aalto, P., Keronen, P., Hakola, H., Bäck, J., Hoffmann, T., Vesala, T., and Hari, P.: A new feedback mechanism linking forests, aerosols, and climate, Atmos. Chem. Phys., 4, 557-562, doi:10.5194/acp-4-557-2004, 2004.

Latta, R. G., Linhart, Y. B., Snyder, M. A., and Lundquist, L.: Patterns of variation and correlation in the monoterpene composition of xylem oleoresin within populations of ponderosa pine, Biochem. Syst. Ecol., 31, 451-465, 2003.

Lauros, J., Sogachev, A., Smolander, S., Vuollekoski, H., Sihto, S.L., Mammarella, I., Laakso, L., Rannik, Ü., and Boy, M.: Particle concentration and flux dynamics in the atmospheric boundary layer as the indicator of formation mechanism, Atmos. Chem. Phys., 11, 5591-5601, doi:10.5194/acp-11-5591-2011, 2011.

Maciag, A., Milakovic, D., Christensen, H. H., Antolovic, V., and Kalemba, D.: Essential oil composition and plant-insect relations in Scots pine (Pinus sylvestris L.), Scientific Bulletin of the Technical University of Lodz 1008, Food Chem. Biotechnol., 71, 7195, 2007.

Manninen, A.-M., Tarhanen, S., Vuorinen, M., and Kainulainen, P.: Comparing the variation of needle and wood terpenoids in Scots pine provenances, J. Chem. Ecol., 28, 211-228, 2002.

Mogensen, D., Smolander, S., Sogachev, A., Zhou, L., Sinha, V., Guenther, A., Williams, J., Nieminen, T., Kajos, M. K., Rinne, J., Kulmala, M., and Boy, M.: Modelling atmospheric OHreactivity in a boreal forest ecosystem, Atmos. Chem. Phys., 11, 9709-9719, doi:10.5194/acp-11-9709-2011, 2011.

Muona, O., Hiltunen, R., Shaw, D. W., and Morén, E.: Analysis of monoterpene variation in natural stands and plustrees of Pinus sylvestris in Finland, Silva Fenn., 20, 1-8, 1986.

Nerg, A., Kainulainen, P., Vuorinen, M., Hanso, M., Holopainen, J. K., and Kurkela, T.: Seasonal and geographical variation of terpenes, resin acids and total phenolics in nursery grown seedlings of Scots pine (Pinus sylvestris L.), New Phytol., 128, 703-713, 1994.

Niinemets, Ü., Seufert, G., Steinbrecher, R., and Tenhunen, J. D.: A model coupling foliar monoterpene emissions to leaf photosynthetic characteristics in Mediterranean evergreen Quercus species, New Phytol., 153, 257-275, 2002.

Niinemets, Ü., Monson, R. K., Arneth, A., Ciccioli, P., Kesselmeier, J., Kuhn, U., Noe, S. M., Peñuelas, J., and Staudt, M.: The leaflevel emission factor of volatile isoprenoids: caveats, model algorithms, response shapes and scaling, Biogeosciences, 7, 18091832, doi:10.5194/bg-7-1809-2010, 2010a.

Niinemets, Ü., Arneth, A., Kuhn, U., Monson, R. K., Peñuelas, J., and Staudt, M.: The emission factor of volatile isoprenoids: stress, acclimation, and developmental responses, Biogeosciences, 7, 2203-2223, doi:10.5194/bg-7-2203-2010, $2010 b$.

Orav, A., Kailas, T., and Liiv, M.: Analysis of terpenoid composition of Conifer Needle Oils by Steam Distillation/Extraction, Gas 
Chromatography and Gas Chromatography-Mass Spectrometry, Chromatographia, 43, 215-219, 1996.

Paasonen, P., Nieminen, T., Asmi, E., Manninen, H. E., Petäjä, T., Plass-Dülmer, C., Flentje, H., Birmili, W., Wiedensohler, A., Hñrrak, U., Metzger, A., Hamed, A., Laaksonen, A., Facchini, M. C., Kerminen, V.-M., and Kulmala, M.: On the roles of sulphuric acid and low-volatility organic vapours in the initial steps of atmospheric new particle formation, Atmos. Chem. Phys., 10, 11223-11242, doi:10.5194/acp-10-11223-2010, 2010.

Pohjola, J.: A Headspace gas chromatographic study on the variation of needle volatile terpenes in Scots pine (Pinus Sylvestris L.), Ph.D. thesis, Pharmacognosy Division, Department of Pharmacy, University of Helsinki, Finland, 1993.

Possell, M., Nicholas. C., and Beerling, D. J.: The effects of glacial atmospheric $\mathrm{CO}_{2}$ concentrations and climate on isoprene emissions by vascular plants, Glob. Change Biol., 11, 60-69, doi:10.1111/j.1365-2486.2004.00889.x, 2005.

Rinne, J., Taipale, R., Markkanen, T., Ruuskanen, T. M., Hellén, H., Kajos, M. K., Vesala, T., and Kulmala, M.: Hydrocarbon fluxes above a Scots pine forest canopy: measurements and modeling, Atmos. Chem. Phys., 7, 3361-3372, doi:10.5194/acp-73361-2007, 2007.

Rinne, J., Bäck, J., and Hakola, H.: Biogenic volatile organic compound emissions from the Eurasian taiga: current knowledge and future directions. Boreal Environ. Res., 14, 807-826, 2009.

Sakulyanontvittaya, T., Guenther, A., Helmig, D., Milford, J., and Wiedinmyer, C.: Secondary organic aerosol from sesquiterpene and monoterpene emissions in the United States, Environ. Sci. Technol., 42, 8784-8790, 2008.

Schurgers, G., Arneth, A., Holzinger, R., and Goldstein, A. H.: Process-based modelling of biogenic monoterpene emissions combining production and release from storage, Atmos. Chem. Phys., 9, 3409-3423, doi:10.5194/acp-9-3409-2009, 2009.

Shao, M., Czapiewski, K.V., Heiden, A.C., Kobel, K., Komenda, M., Koppmann, R., and Wildt, J.: Volatile organic compound emissions from Scots pine: Mechanisms and description by algorithms, J. Geophys. Res., 106, 20483-20491, 2001.

Sjödin, K., Persson, M., Fäldt, J., Ekberg, I., and Borg-Karlson, A.-M.: Occurence and correlations of monoterpene hydrocarbon enantiomers in Pinus sylvestris and Picea abies, J. Chem. Ecol., 26, 1701-1720, 2000.

Sogachev, A. and Panferov, O.: Modification of two-equation models to account for plant drag, Bound.-Lay. Meteorol., 121, 229266, 2006.
Sogachev, A., Menzhulin, G., Heimann, M., and Lloyd, J.: A simple three dimensional canopy planetary boundary layer simulation model for scalar concentrations and fluxes, Tellus B, 54, 784819, 2002.

Squillace, A. E.: Inheritance of monoterpene composition in cortical oleoresin of Slash pine, Forest Sci., 17, 381-387, 1971.

Staudt, M., Bertin, N., Hansen, U., Seufert, G., Ciccioli, P., Foster, P., Frenzel, B., and Fugit J.-L.: Seasonal and diurnal patterns of monoterpene emissions from Pinus pinea, Atmos. Environ., 31, 145-156, 1997.

Tarvainen, V., Hakola, H., Hellén, H., Bäck, J., Hari, P., and Kulmala, M.: Temperature and light dependence of the VOC emissions of Scots pine, Atmos. Chem. Phys., 5, 989-998, doi:10.5194/acp-5-989-2005, 2005.

Tarvainen, V., Hakola, H., Rinne, J., Hellén, H., and Haapanala, S.: Towards a comprehensive emission inventory of terpenoids from boreal ecosystems, Tellus B, 59, 526-534, 2007.

Thoss, V., O'Reilly-Wapstra, J., and Iason, G. R.: Assessment and implications of intraspecific and phenological variability in monoterpenes of Scots pine (Pinus sylvestris) foliage, J. Chem. Ecol., 33, 477-491, 2007.

Tingey, D. T., Manning, M., Grothaus, L. C., and Burns, W. F.: Influence of light and temperature on monoterpene emission rates from Slash Pine, Plant Physiol., 65, 797-801, 1980.

Tunved, P., Hansson, H.-C., Kerminen, V.-M., Ström, J., Dal Maso, M., Lihavainen, H., Viisanen, Y., Aalto, P. P., Komppula, M., and Kulmala, M.: High Natural Aerosol Loading over Boreal Forests, Science, 312, 261-263, 2006.

Yadzani, R., Nilsson, J. E., and Ericsson, T.: Geograqphical variation in the relative proportion of monoterpenes in cortical oleoresin of Pinus sylvestris in Sweden, Silvae Genet., 34, 201-208, 1985.

Vesala, T., Suni, T, Rannik, Ü., Keronen, P., Markkanen, T., Sevanto, S., Grönholm, T., Smolander, S., Kulmala, M., Ilvesniemi, H., Ojansuu, R., Uotila, A., Levula, J., Mäkelä, A., Pumpanen, J., Kolari, P., Kulmala, L., Altimir, N., Berninger, F., Nikinmaa, E., and Hari, P.: Effect of thinning on surface fluxes in a boreal forest, Global Biogeochem. Cy., 19, GB2001, doi:10.1029/2004GB002316, 2005. 